\title{
A novel 96-microwell-based high-throughput spectrophotometric assay for pharmaceutical quality control of crizotinib, a novel potent drug for the treatment of non-small cell lung cancer
}

\author{
Tanveer Ahmed Wani, Ibrahim Ali Darwish*
}

Department of Pharmaceutical Chemistry, College of Pharmacy, King Saud University, Riyadh, Saudi Arabia

\begin{abstract}
This study describes the development and validation of a novel 96-microwell-based high throughput spectrophotometric assay for pharmaceutical quality control of crizotinib (CZT), a novel drug for the treatment of non-small cell lung cancer. We examined the reaction between CZT and 1,2-naphthoquinone4-sulphonate, a chromogenic reagent. A red-colored product showing a maximum absorption peak $\left(\lambda_{\max }\right)$ at $490 \mathrm{~nm}$ was produced in an alkaline medium ( $\mathrm{pH}$ 9). We examined stoichiometry of the reaction and postulated the reaction mechanism. To our knowledge, this is the first study to describe a color-developing reaction for the proposed assay. The reaction was performed in a 96-microwell plate, and the absorbance of the colored product was measured using an absorbance reader at $490 \mathrm{~nm}$. Under optimized reaction conditions, Beer's law, which shows a correlation between absorbance and CZT concentration, was obeyed in the range of 4-50 $\mu \mathrm{g} /$ well with an appropriate correlation coefficient (0.999). The limits of detection and quantification were 1.73 and $5.23 \mu \mathrm{g} / \mathrm{well}$, respectively. The assay showed high precision and accuracy. The proposed assay was applied successfully for the determination of CZT in capsules. Thus, the assay proposed in this study is practical and valuable for routine application in pharmaceutical quality control laboratories.
\end{abstract}

Uniterms: Crizotinib/capsules/quality control. 1,2-Naphthoquinone-4-sulphonate. Spectrophotometry/ quality control of medicines.

Este estudo descreve o desenvolvimento e a validação de um novo ensaio espectrofotométrico em larga escala em 96 micropoços para o controle farmacêutico de crizotinibe (CZT), novo fármaco para o tratamento de câncer de pulmão de células não pequenas. Examinamos a reação entre o CZT e o 4-sulfonato de 1,2-naftoquinona, um reagente cromogênico. Obteve-se, em meio alcalino ( $\mathrm{pH}$ 9), produto vermelho, com absorção máxima $\left(\lambda_{\max }\right)$ em $490 \mathrm{~nm}$. Examinamos a estequiometria da reação e propusemos mecanismo de reação. Este, segundo nosso conhecimento, é o primeiro estudo para descrever reação de desenvolvimento de cor para o ensaio proposto. A reação foi realizada em placas de 96 micropoços e mediu-se a absorbância do produto colorido utilizando-se leitor de absorbância a $490 \mathrm{~nm}$. Sob condições otimizadas de reação, a lei de Beer, que mostra a correlação entre a absorbância e a concentração de CZT, foi obedecida na faixa de 4-50 $\mu \mathrm{g}$ /poço, com coeficiente de correlação apropriado $(0,999)$. Os limites de detecção e de quantificação foram, respectivamente, 1,73 e 5,23 $\mu \mathrm{g} /$ poço. O ensaio mostrou alta precisão e exatidão. O ensaio proposto foi aplicado com sucesso para a determinação de CZT em cápsulas e é prático e válido para a aplicação de rotina em laboratórios de controle farmacêutico.

Unitermos: Crizotinibe/cápsulas/controle de qualidade. 4-Sulfonato de 1,2-naftoquinona. Espectrofotometria/controle de qualidade de medicamentos.

\footnotetext{
*Correspondence: I. A. Darwish. Department of Pharmaceutical Chemistry.
} College of Pharmacy. King Saud University. Riyadh, Saudi Arabia. E-mail: idarwish@ksu.edu.sa 


\section{INTRODUCTION}

Lung cancer is the most common cancer worldwide in men and women in terms of both incidence and mortality. In 2008, there were 1.61 million new cases and 1.38 million deaths because of lung cancer (WHO, 2005; Ferlay et al., 2010). The most common causes of lung cancer are air pollution, genetic factors, and longterm exposure to tobacco smoke, radon gas, and asbestos (O'Reilly et al., 2007). Most primary lung carcinomas are derived from epithelial cells. The main types of lung cancers are small-cell lung cancer and non-small cell lung cancer (NSCLC). NSCLC accounts for approximately $85 \%$ of all lung cancers. These cancer cells grow quickly and spread early in the course of the disease. Surgery, radiotherapy, and chemotherapy are the main treatment options for NSCLC. Surgery and radiotherapy are usually considered for localized stage I and stage II of NSCLC; however, these treatment options are not feasible for advanced NSCLC (Strand et al., 2011; Rowell, Williams, 2001; Stand et al., 2011). Chemotherapy is the treatment of choice for approximately $80 \%$ of all patients with NSCLC (Tan et al., 2013). Multiple randomized controlled trials and large meta-analyses have confirmed the superiority of chemotherapy regimens for advanced NSCLC (NSCLC, 2008; NSCLC, 2013). Chemotherapy is used as the first-line treatment for patients with advanced metastatic or localized NSCLC, and it improves the survival and quality of life if the patient is well enough for the treatment (Burdett et al., 2008; NSCLC, 2010). Typically, first-generation tyrosine kinase inhibitors (e.g., gefinitinib and erlotinib) have been used for the treatment of NSCLC (Cohen et al., 2004; Johnson et al., 2005). A considerable number of NSCLC patients have a chromosomal rearrangement that generates a fusion gene between echinoderm microtubule-associated protein like 4 (EML4) and anaplastic lymphoma kinase (ALK), which results in constitutive kinase activity that contributes to increased cell carcinogenesis and drives the malignant phenotype (Tan, Harris, Huq, 2013; Ron, 2010; Pfizer Oncology, 2014 (Link com erro, data corresponde ao dia do acesso e não a data do documento). Patients with this fusion gene are typically young non-smokers who do not have mutations in either the epidermal growth factor receptor (EGFR) gene or in the K-Ras gene (Alberg, Samet, 2010 (falta referência); O'Reilly et al., 2007). First-generation tyrosine kinase inhibitors do not inhibit the kinase activity of the fusion protein, and thus, studies were performed to discover an alternative novel drug for the treatment of patients with NSCLC, including those with tumors harboring EML4-ALK fusion proteins.
Crizotinib (CZT; Figure 1) is a novel small-molecule inhibitor of tyrosine kinase. CZT acts by competitive binding with the ATP-binding pocket of target kinases (Sai-Hong, 2011(falta referência); Rodig, Shapiro, 2010; Kwak et al., 2010; Cui et al., 2011). CZT causes tumor shrinkage in $90 \%$ of patients carrying the ALK fusion gene (Kris, 2011 (na referência a data é 2011). On the basis of two successful clinical multi-center studies, CZT was granted an accelerated approval by the Food and Drug Administration (FDA) on August 26, 2011 (under the trade name of Xalkori ${ }^{\circledR}$ capsules made by Pfizer, Inc.) for the treatment of patients with advanced local or metastatic NSCLC that is ALK-positive as detected by the FDAapproved test (Abbot Molecular, Inc.) (NIH,, 2011).

Effective and safe therapy with CZT mainly depends on the quality of its pharmaceutical formulation (Xalkori capsules). For the pharmaceutical quality control (QC) of CZT, a proper analytical method with high throughput is required. Previous studies showed that to date, no analytical method is available for the determination of CZT in its bulk or in capsules. Spectrophotometry has considerable importance in drug analysis, and photometric methods are extensively applied for the determination of active substances in bulk drugs and pharmaceutical preparations (Görög, 1994). However, the conventional spectrophotometric methods are not automated and their throughputs are low; thus, their practical applications in pharmaceutical QC laboratories are limited.

In this study, we described the development of a new 96-microwell-based high-throughput spectrophotometric assay for the QC of CZT. This assay was based on the reaction of CZT with 1,2-naphthoquinone-4-sulphonate (NQS) in an alkaline buffered medium to produce a red-colored product. The reaction was performed in a 96-microwell assay plate, and the absorbance was measured using a microwell-plate absorbance reader.

\section{MATERIAL AND METHODS}

\section{Apparatus}

A microwell-plate absorbance reader (ELx 808; BioTek Instruments Inc., Winooski, USA) empowered by the Gen5 software (provided with the instrument) was used for all the measurements in 96-microwell plates. UV-1601 PC double-beam ultraviolet-visible spectrophotometer (Shimadzu, Kyoto, Japan) with matched 1-cm quartz cells was used for recording the absorption spectra. We used a pH meter model 350 from Bibby Scientific Ltd., T/As Jenway, Essex, England. 96-Microwell plates were purchased from Corning/Costar Inc. (Cambridge, USA). 
Finnpipette adjustable 8-channel-pipette was purchased from Sigma Chemical Co. (St. Louis, MO, USA).

\section{Reagents and materials}

CZT was purchased from Haoyuan Chemexpress Co., Ltd. (Shanghai, China) and used as received; the purity of the investigated compound was $>99 \%$, and the solution was stable for at least one month when kept refrigerated. An aqueous solution $(0.1 \%, \mathrm{w} / \mathrm{v})$ of NQS (Aldrich Chemical Co., St. Louis, USA) was freshly prepared and protected from light during use. Buffer solutions (Clark, tris, phthalate, borate, phosphate, and carbonate) were prepared as previously described (Pesez, Bartos, 1974). We used Xalkori capsules (Pfizer Inc., New York, NY, USA) labeled to contain $250 \mathrm{mg}$ CZT per capsule. Double distilled water was obtained using the WSC-85 water purification system (Hamilton Laboratory Glass Ltd., Kent, USA) and used throughout the experiment. All solvents and materials used in this study were of analytical grade.

\section{Preparation of solutions}

\section{Standard CZT solution}

An accurately weighed amount ( $25 \mathrm{mg}$ ) of CZT was quantitatively transferred into a $25-\mathrm{mL}$ calibrated flask, dissolved in $20 \mathrm{~mL}$ methanol, completed to volume with the same solvent to obtain a stock solution of $1 \mathrm{mg} / \mathrm{mL}$. The stock solution was stable for at least two weeks when under refrigerated conditions. The stock solution was further diluted with methanol to obtain working solutions in the range of $4-50 \mu \mathrm{g} /$ well $(50 \mu \mathrm{L})$.

\section{Capsule sample solution}

The contents of 10 Xalkori capsules were emptied and weighed. An accurately weighed quantity of the capsule contents equivalent to $25 \mathrm{mg}$ of CZT was transferred into a $25-\mathrm{mL}$ calibrated flask and dissolved in $15 \mathrm{~mL}$ of methanol. The contents of the flask were swirled, sonicated for $20 \mathrm{~min}$, and then, completed to volume with methanol. The contents were mixed well and centrifuged at $6000 \mathrm{rpm}$ for $10 \mathrm{~min}$; the supernatant was separated and filtered, and the first portion of the filtrate was rejected. The filtered solution was diluted quantitatively with methanol to obtain suitable concentrations for analysis using the proposed assay.

\section{General recommended assay procedures}

An accurately measured volume $(50 \mu \mathrm{L})$ of CZT solution containing 4-50 $\mu \mathrm{g} /$ well $(50 \mu \mathrm{L})$ was transferred into a 96-microwell plate. Subsequently, we added $25 \mu \mathrm{L}$ of Clark's buffer solution, $\mathrm{pH} 9$, and $50 \mu \mathrm{L}$ of NQS solution $(0.1 \%, \mathrm{w} / \mathrm{v})$. The reaction was allowed to proceed for $15 \mathrm{~min}$ at room temperature $\left(25 \pm 2{ }^{\circ} \mathrm{C}\right)$, and then, $100 \mu \mathrm{L}$ of methanol was added to each well. The absorbance of the resulting solution was measured at $490 \mathrm{~nm}$.

\section{Determination of the molar ratio of NQS:CZT}

We prepared master solutions of varying concentrations of NQS $\left(0.025-4 \times 10^{-3} \mathrm{~mol} / \mathrm{L}\right)$ and a CZT solution of a fixed concentration $\left(1 \times 10^{-3} \mathrm{~mol} / \mathrm{L}\right)$. Then, we transferred an accurately measured volume $(50 \mu \mathrm{L})$ of the CZT solution into each well of the 96-microwell plate followed by the addition of $25 \mu$ L Clark's buffer solution, pH 9. Further, we added $50-\mu \mathrm{L}$ aliquots of varying concentrations of NQS solution to the microwellassay plate to prepare various molar ratios of NQS:CZT (4-1). The reaction solutions were further manipulated as described in the general recommended assay procedures. The measured absorbances were plotted as a function of the NQS:CZT molar ratio. The plot was used for the determination of the molar ratio of the reaction between CZT and NQS.

\section{RESULTS AND DISCUSSION}

\section{Strategy for assay development and its design}

We recorded the absorption spectrum of CZT solution $(50 \mu \mathrm{g} / \mathrm{mL}$, in methanol) (Figure 1). The absorption spectrum showed that CZT has two maximum absorption peaks $\left(\lambda_{\max }\right)$ at 270 and $320 \mathrm{~nm}$. These blue-shifted $\lambda_{\max }$ introduce potential interference in the spectrophotometric assay for QC of CZT based on its native UV light absorption from the excipients in its dosage form (capsules). Therefore, development of a visible spectrophotometric assay for CZT is important. This assay enables the use of simple inexpensive instruments that are equipped with color measuring detection systems that are available in most QC laboratories. Therefore, in this study, we developed a visible spectrophotometric assay for the determination of CZT in bulk and capsules.

For the development of a visible spectrophotometric assay for CZT, a color-developing reaction was required. CZT contains a piperazinyl amino group and a primary aromatic amino group; thus, many reagents can be used for the color-producing reaction (Görög, 1994; Toyo'oka, 1999). These reactions involve formation of colored charge-transfer complexes with electron acceptors, 
formation of ion-pair associates with pairing reagents, and formation of condensation products with chromogenic reagents. These methods are usually associated with some major drawbacks such as laborious multiple extraction steps in the analysis using ion-pair based methods, consumption of large volumes of organic solvents in ionpair- and charge transfer-based methods, and long time required for some condensation reactions. Therefore, in this study, we aimed to develop an alternative simple color reaction for quantification of CZT using a new visible spectrophotometric assay.

Previously, Darwish et al. $(2009,2012)$ showed that NQS is a convenient and valuable color-developing reagent in the development of simple spectrophotometric methods for the determination of many pharmaceutical amines. The reaction between CZT and NQS has not been investigated thus far. The CZT molecule has two anticipated reactive centers, which are the piperazinyl amino group and the primary aromatic amino group. Therefore, we investigated the reaction between NQS and CZT, and the use of this color reaction in the development of a new simple and rapid high-throughput spectrophotometric assay for the determination of CZT in bulk and capsules.

The reaction between CZT and NQS was performed in a $96-$ microwell assay plate $(200-\mu \mathrm{L}$ total reaction volume). The solutions were dispensed using an 8 -channel pipette, and the absorbance of the colored-reaction product was measured using a 96-microwell-plate absorbance reader. We used the 96-microwell design in this assay on the basis of the previous studies by Darwish et al. $(2013,2014)$ for high-throughput analysis of some other pharmaceuticals. These studies are described below.

\section{Absorption spectra and optimization of reaction conditions}

The reaction between CZT and NQS was performed, and the absorption spectrum of the reaction product was recorded against reagent blank. The reaction product was red colored and showed $\lambda_{\max }$ at $490 \mathrm{~nm}$ depending on CZT concentrations (Figure 1). The experimental conditions affecting the reaction in the 96-microwell format were optimized by altering each reaction variable in a turn while keeping the others constant.

The absorbance of the reaction product between NQS and CZT increased with an increase in the concentration NQS (Figure 2A). The highest value was obtained at a concentration of $0.08 \%(\mathrm{w} / \mathrm{v})$; the absorbance values remained constant beyond this concentration. A concentration of $0.1 \%(\mathrm{w} / \mathrm{v})$ was used in all the subsequent experiments.

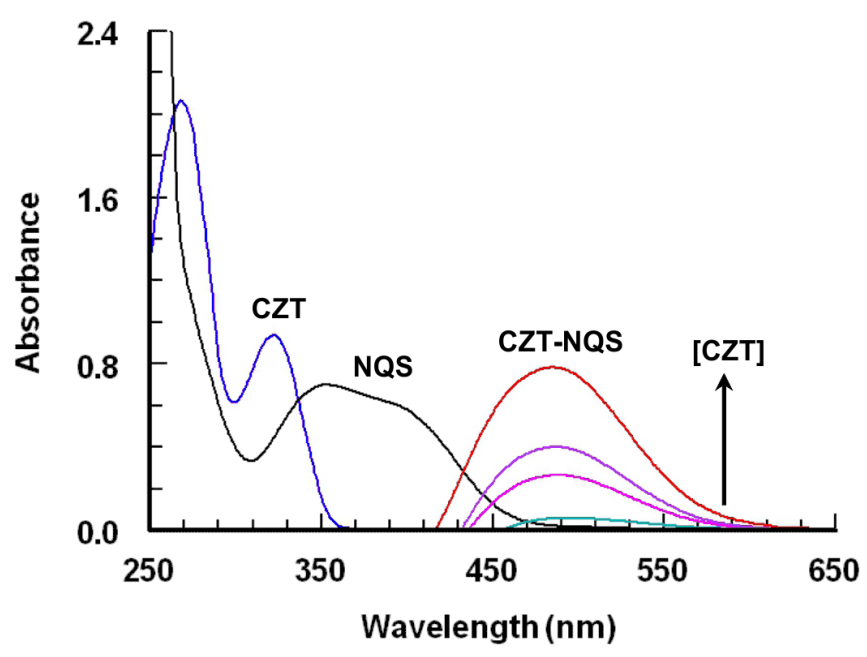

FIGURE 1 - Absorption spectra of crizotinib (CZT) against methanol, 1,2-naphthoquinone-4-sulphonate (NQS) against water, and CZT-NQS reaction product at varying CZT concentrations against reagent blank.

The influence of $\mathrm{pH}$ on the reaction of CZT with NQS was investigated by performing the reaction in a buffer solution of varying $\mathrm{pH}$ values ( $\mathrm{pH} 7-10)$. The results showed that the reaction was dependent on the $\mathrm{pH}$ because the absorbance increased with $\mathrm{pH}$, and the maximum value of absorbance was observed in the $\mathrm{pH}$ range of 8.5-10 (Figure 2B). A high reactivity was observed at an alkaline $\mathrm{pH}$ because the alkaline $\mathrm{pH}$ did not alter the amino group of CZT, and thus, facilitated nucleophilic substitution with the NQS reagent. All subsequent experiments were performed at $\mathrm{pH} 9$. To investigate the effect of the buffer components on the reaction, we examined different buffer solutions adjusted at $\mathrm{pH} 9$ as follows: Clark's, carbonate, phosphate, borate, phathalate, and tris buffers. The highest readings were obtained when Clark's buffer was used (data not shown); therefore, we used Clark's buffer for all the subsequent experiments.

To determine the optimum time required for the completion of the reaction, we allowed the reaction to proceed at room temperature for different periods of time. We observed that the reaction was almost completed within $10 \mathrm{~min}$ (Figure 2C); however, to obtain readings with a high precision, the reaction was allowed to proceed for $15 \mathrm{~min}$.

A summary of the optimum conditions for the reaction between CZT and NQS is given in Table I.

\section{Stoichiometry and mechanism of the reaction}

Under the optimum conditions (Table I), we determined the stoichiometry of the reaction between CZT and NQS. We observed that the CZT:NQS ratio was 1:2 (Figure 2D). This indicated that two sites of interaction 

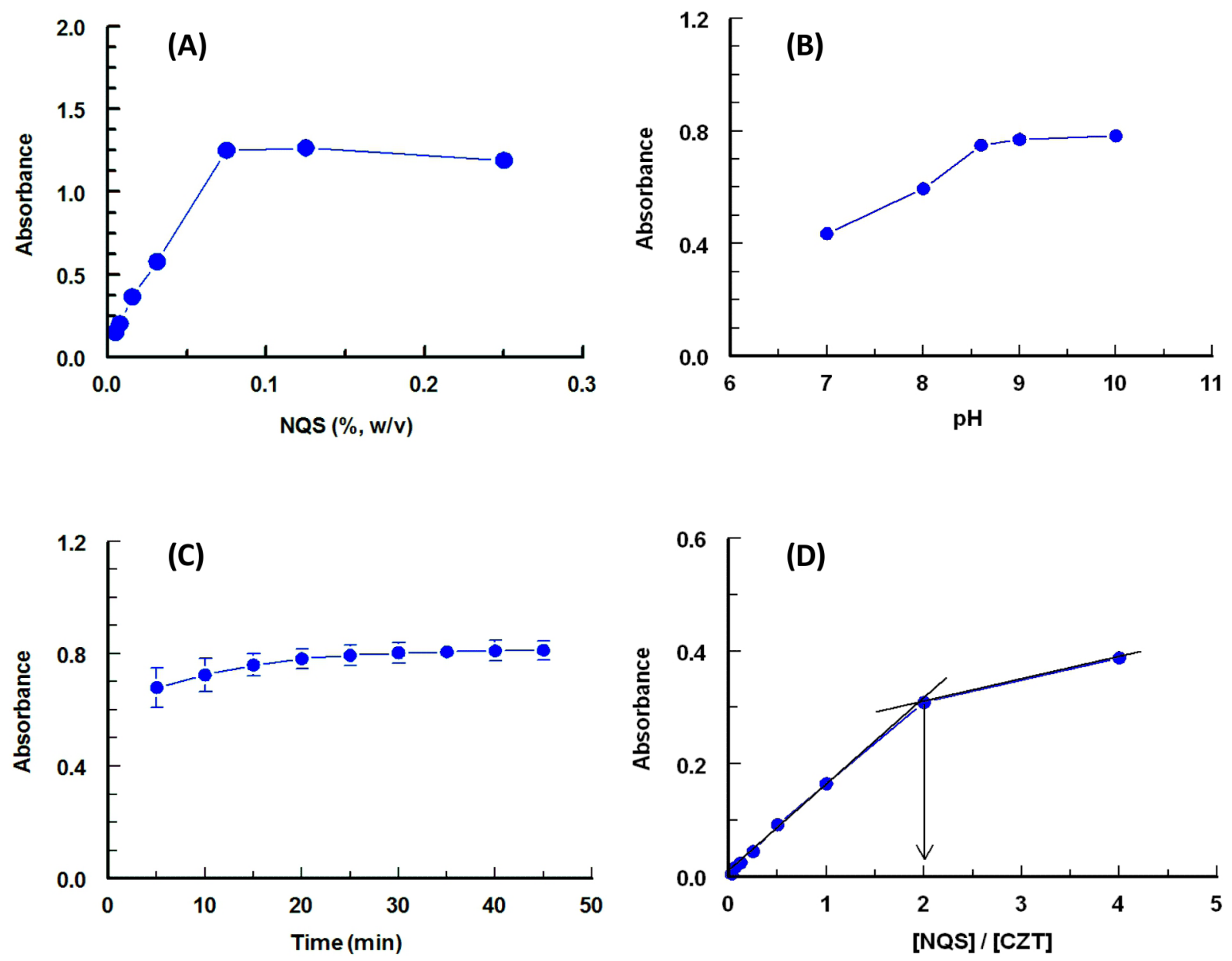

FIGURE 2 - Effect of different 1,2-naphthoquinone-4-sulphonate (NQS) concentrations (A), pH (B), and time (C) on the reaction between crizotinib (CZT) and NQS, and the reaction molar ratio (D).

TABLE 1 - Summary of the optimization of variables affecting the reaction between CZT and NQS reagent used in the development of the proposed 96-microwell-based spectrophotometric assay for crizotinib (CZT)

\begin{tabular}{lcc}
\hline Variable & Studied range & Optimum \\
\hline $\begin{array}{l}\text { NQS concentration } \\
(\%, w / v)\end{array}$ & $0.01-0.25$ & 0.1 \\
pH & $7-10$ & 9 \\
Time (min) & $5-45$ & 15 \\
Measuring & $400-650$ & 490 \\
wavelength (nm) & & \\
\hline
\end{tabular}

on the CZT molecule were involved in the formation of the colored CZT-NQS product, and two NQS molecules were required for the formation of the reaction product. These two sites were the piperazinyl amino group and the primary aromatic amino group. On the basis of these results, we postulated the reaction pathway (Figure 3).

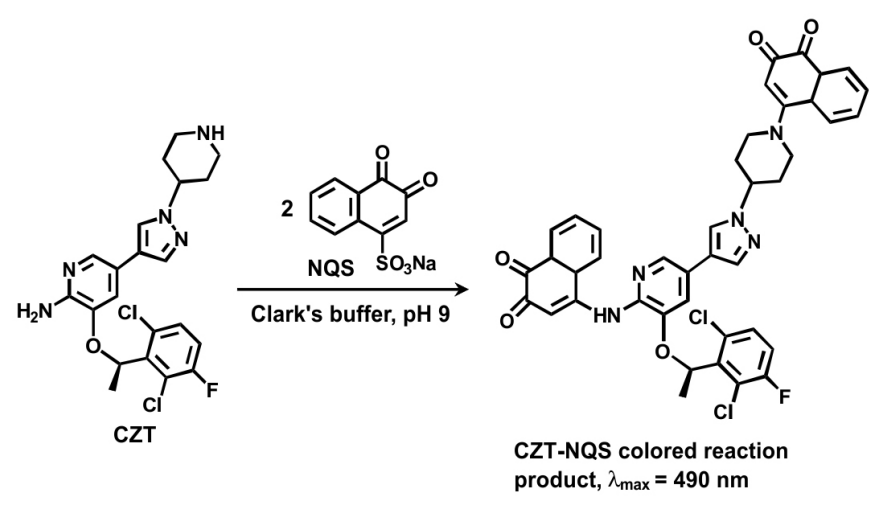

FIGURE 3 - Proposed mechanism of the reaction between crizotinib (CZT) and 1,2-naphthoquinone-4-sulphonate (NQS).

\section{Validation of the assay}

\section{Calibration and sensitivity}

Under the optimum reaction conditions (Table I), we constructed the calibration curve for determining the CZT concentration upon its reaction with NQS by 
plotting the absorbances as a function of the corresponding concentrations (Figure 4). The regression equation for the results was $\mathrm{A}=0.0085+0.0370 \mathrm{C}(\mathrm{r}=0.999)$, where A is the absorbance at $490 \mathrm{~nm}, \mathrm{C}$ is the concentration of $\mathrm{CZT}$ in $\mu \mathrm{g} / \mathrm{well}$ in the range of $4-50 \mu \mathrm{g} / \mathrm{well}$, and $\mathrm{r}$ is the correlation coefficient. The limit of detection (LOD) and limit of quantification (LOQ) were determined according to the International Conference of Harmonization (ICH) guidelines for validation of analytical procedures $(\mathrm{ICH}$, 1996). We used the following: $\mathrm{LOD}$ or $\mathrm{LOQ}=\times \mathrm{SDa} / \mathrm{b}$, where $x=3.3$ for LOD and 10 for LOQ, SDa is the standard deviation of the intercept, and $\mathrm{b}$ is the slope. The LOD and LOQ were 1.73 and $5.23 \mu \mathrm{g} / \mathrm{well}$, respectively.

The parameters for the analytical performance of the proposed method are summarized in (Table II).

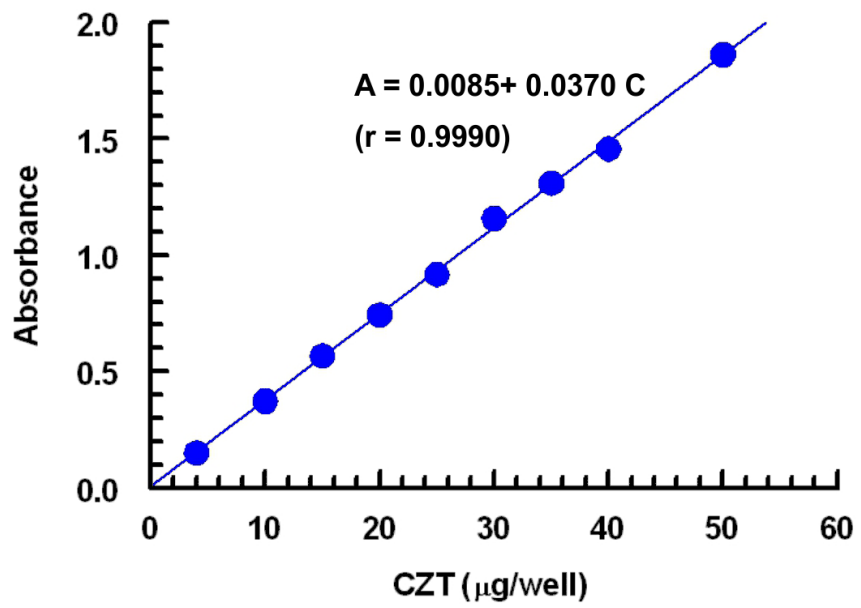

FIGURE 4 - Calibration curve for the determination of crizotinib (CZT) concentration by using the 96-microwell spectrophotometric assay on the basis of its reaction with 1,2-naphthoquinone-4-sulphonate (NQS).

\section{Precision}

The intra-assay precision of the proposed method was determined using different concentrations of the drug solution and analyzing 6 replicates of each concentration as a batch in a single assay run. The inter-assay precision was determined by analyzing the same samples as duplicates on three consecutive days. The relative standard deviations (RSD) did not exceed $2 \%$, which proved the high precision of the proposed assay for routine application in the analysis of CZT in QC laboratories.

\section{Accuracy, selectivity, and interference liabilities}

The accuracy of the proposed assay was evaluated by determining the recovery rates of different concentrations of CZT. The recovery values were $98.2-99.7 \pm 1.24-1.79 \%$,
TABLE II - Quantitative parameters for the analytical performance of the proposed 96-microwell-based spectrophotometric assay for crizotinib (CZT)

\begin{tabular}{lc}
\hline Parameter & Value \\
\hline Linear range $(\mu \mathrm{g} /$ well) & $4-50$ \\
Intercept $(\mathrm{a})$ & 0.0085 \\
Standard deviation of the intercept & 0.0194 \\
Slope & 0.0370 \\
Correlation coefficient & 0.999 \\
Limit of detection, LOD ( $\mu \mathrm{g} / \mathrm{well})$ & 1.73 \\
Limit of quantification, LOQ $(\mu \mathrm{g} /$ well) & 5.23 \\
Precision $(\mathrm{RSD}, \%)$ & $<2$ \\
Accuracy (recovery, \%) & $>98$ \\
\hline
\end{tabular}

which indicated the accuracy of the proposed assay. The advantages of the proposed assay are that the measurements are performed in the visible region, away from the UV-absorbing interfering substances that might be co-extracted from dosage forms containing CZT. Before analyzing the amount of CZT in its dosage form (capsules), interference liabilities were performed to explore the effect of inactive ingredients that might be added during formulation of CZT capsules (Xalkori, 2013). The samples were prepared by mixing a known amount $(250 \mathrm{mg})$ of CZT with $50 \mathrm{mg}$ of microcrystalline cellulose, $10 \mathrm{mg}$ of colloidal silicon dioxide, $5 \mathrm{mg}$ of anhydrous dibasic calcium phosphate, $5 \mathrm{mg}$ of sodium starch glycolate, and $5 \mathrm{mg}$ of magnesium stearate. These laboratory-prepared samples were analyzed using the proposed method by applying the general recommended procedure. The recovery values ranged from $96.2 \pm 1.04$ to $102.1 \pm 1.46 \%$ (Table III). These data confirmed the absence of interference from any of the inactive ingredients during the determination of CZT by using the proposed assay.

\section{Application for analysis of CZT in capsules}

Our results indicate that the proposed method yielded satisfactory results with CZT in bulk powder. Further, we used this method for the determination of CZT concentration in its pharmaceutical dosage form (Xalkori capsules). The percentage found from the label claim was $99.82 \pm 1.24 \%$. The good recovery values indicated the reliability of the proposed assay for routine application for the accurate determination of CZT in pharmaceutical QC laboratories. 
TABLE III - Analysis of crizotinib (CZT) in presence of excipients present in its capsules by using the proposed 96-microwell-based spectrophotometric assay

\begin{tabular}{lc}
\hline Excipient & Recovery (\% \pm SD) \\
\hline Microcrystalline cellulose (50) & $101.4 \pm 1.25$ \\
Colloidal silicon dioxide (10) & $96.2 \pm 1.04$ \\
Anhydrous dibasic calcium & $98.9 \pm 1.31$ \\
phosphate (5) & $102.1 \pm 1.46$ \\
Sodium starch glycolate (5) & $99.7 \pm 0.87$ \\
Magnesium stearate (5) &
\end{tabular}

a Values are mean of three determinations. ${ }^{\mathrm{b}}$ Figures in parenthesis are the amounts (in $\mathrm{mg}$ ) that were added per 250 mg of CZT.

\section{CONCLUSIONS}

This study described the successful development of a new 96-microwell-based spectrophotometric assay for the accurate determination of CZT in its bulk and capsules based on its derivatization with NQS as a chromogenic analytical reagent. The assay described herein offered the following advantages:

- This method uses an inexpensive, stable reagent with excellent shelf life, and the reagent is available in any pharmaceutical QC laboratory.

- This method provides a high-throughput analytical method that can be used to analyze a large number of samples in a relatively short time. This property was attributed to using multi-channel pipettes for efficient dispensing of the solutions, performing the analytical reaction in 96-well plates (as reaction vessels), and measuring the color signals in the 96 wells at $\sim 30$ s using the plate reader.

- This method used minimum volumes of reagent and organic solvents (environmentally friendly "Green" approach), and thus, decreased cost of analysis and the exposures of the analysts to the toxic effects of organic solvents.

\section{ACKNOWLEDGMENTS}

The authors would like to extend their gratitude to the Deanship of Scientific Research at King Saud University for its funding of this research through the research group project No. RGP-VPP-225.

\section{REFERENCES}

BURDETT, S.; STEPHENS, R.; STEWART, L.; TIERNEY, J.; AUPERIN, A.; LE CHEVALIER, T.; LE PECHOUX, C.; PIGNON, J.; ARRIAGADA, R.; HIGGINS, J. Chemotherapy in addition to supportive care improves survival in advanced non-small-cell lung cancer: a systematic review and meta-analysis of individual patient data from 16 randomized controlled trials. J. Clin. Oncol., v.26, n.28, p.4617-4625, 2008.

COHEN, M.H.; WILLIAMS, G.A.; SRIDHARA, R.; CHEN, G.; MCGUINN, W.D.; MORSE, D.; ABRAHAM, S.; RAHMAN, A.; LIANG, C.; LOSTRITTO, R; BAIRD, A.; PAZDUR, R. United States Food and Drug Administration drug approval summary: gefitinib (ZD1839; Iressa) tablets. Clin. Cancer Res., v.10, n.4, p.1212-1218, 2004.

CUI, J.J.; TRAN-DUBE, M.; SHEN, H.; NAMBU, M.; KUNG, P.P.; PAIRISH, M.; JIA, L.; MENG, J.; FUNK, L.; BOTROUS, I.; MCTIGUE, M.; GRODSKY, N.; RYAN, K.; PADRIQUE, E.; ALTON, G.; TIMOFEEVSKI, S.; YAMAZAKI, S.; LI, Q.; ZOU, H.; CHRISTENSEN, J.; MROCZKOWSKI, B.; BENDER, S.; KANIA, R. S.; EDWARDS, M. P. Structure based drug design of crizotinib (pf-02341066), a potent and selective dual inhibitor of mesenchymal-epithelial transition factor (c-met) kinase and anaplastic lymphoma kinase (ALK). J. Med. Chem., v.54, n. 18, p.6342-6363, 2011.

DARWISH, I.A.; ABDINE, H.H.; AMER, S.M.; AL-RAYES, L.I. Simple spectrophotometric method for the determination of paroxetine in tablets using 1,2-naphthoquinone-4sulphonate as a chromogenic reagent. Int. J. Anal. Chem., v.2009, p.1-8, 2009.

DARWISH, I.A.; AL-SHEHRI, M.M.; EL-GENDY, M.A., Novel spectrophotometric method for determination of cinacalcet hydrochloride in its tablets via derivatization with 1,2-naphthoquinone-4-sulphonate. Chem. Cent. J., v.6, n.11, p.1-8, 2012.

DARWISH, I.A.; ASKAL, H.F.; REFAAT, I.H.; MARZOUQ, M.A.; AHAMAD, S.R. Novel microwell-based spectrophotometric method with high throughput for determination of 4-quinolone antibiotics in their pharmaceutical formulations via spontaneous formation of water soluble ion-pair complexes. Lat. Am. J. Pharm., v.32, n.9, p.1273-1279, 2013. 
DARWISH, I.A.; WANI, T.A.; ALQARNI, M.A.; AHAMAD, S.R. Microwell-based spectrophotometric method for determination of azithromycin in its pharmaceutical formulations via charge transfer reaction with 2,3-dichloro5,6-dicyano-1,4-benzoquinone. Lat. Am. J. Pharm., v.33, n.4, p.587-594, 2014.

FERLAY, J.; SHIN, H.R.; BRAY, F.; FORMAN, D.; MATHERS, C.; PARKIN, D.M. Estimates of worldwide burden of cancer in 2008: GLOBOCAN 2008. Int. J. Cancer, v.127, n.12, p.2893-2917, 2010.

NATIONAL CANCER INSTITUTE. NIH. . FDA approval for crizotinib. Posted on 29 Aug. 2011. Available at: <http:// www.cancer.gov/cancertopics/druginfo/fda-crizotinib>. Accessed on: 26 March 2014.

GÖRÖG, S. Ultraviolet-visible spectrophotometry in pharmaceutical analysis. New York: CRC Press, 1994. p. 173-215.

INTERNATIONAL CONFERENCE ON HARMONIZATION. ICH. Guideline Q2-R1: validation of analytical procedures: text and methodology. [S.1.]: International Conference on Harmonization, 1996. 13 p.

JOHNSON, J.R.; COHEN, M.; SRIDHARA, R.; CHEN, Y.F.; WILLIAMS, G.M.; DUAN, J.; GOBBURU, J.; BOOTH, B.; BENSON, K.; LEIGHTON, J.; HSIEH, L. S.; CHIDAMBARAM, N.; ZIMMERMAN, P.; PAZDUR, R. Approval summary for erlotinib for treatment of patients with locally advanced or metastatic non-small cell lung cancer after failure of at least one prior chemotherapy regimen. Clin. Cancer Res., v.11, n.18, p.6414-6421, 2005.

KRIS, M.G. ALK inhibitor crizotinib has high response rate in patients with ALK-positive NSCLC. HemOncToday, [News]. June 2010. Available at: <http://goo.gl/T8VZpD>. Accessed on: 26 March 2014.

KWAK, E.L.; BANG, Y.J.; CAMIDGE, D.R.; SHAW, A.T.; SOLOMON, B.; MAKI, R.G.; OU, S.H.; DEZUBE, B.J.; JANNE, P.A.; COSTA, D.B.; VARELLA-GARCIA, M.; KIM, W.H.; LYNCH, T.J.; FIDIAS, P.; STUBBS, H.; ENGELMAN, J.A.; SEQUIST, L.V.; TAN, W.; GANDHI, L.; MINO-KENUDSON, M.; WEI, G.C.; SHREEVE, S.M.; RATAIN, M.J.; SETTLEMAN, J.; CHRISTENSEN, J.G.; HABER, D.A.; WILNER, K.; SALGIA, R.; SHAPIRO, G.I.; CLARK, J.W.; IAFRATE, A.J. Anaplastic lymphoma kinase inhibition in non-small-cell lung cancer. New Eng. J. Med., v.363, n.18, p.1693-1703, 2010.
KRIS, M.G. Maintenance therapy for non-small cell lung cancer. Medscape CME 05 December 2011. Available at: <http:// cme.medscape.com/viewarticle/720896_transcript $>$. Accessed on: 26 March 2014.

NON-SMALL CELL LUNG CANCER COLLABORATIVE GROUP. NSCLC. Chemotherapy and supportive care versus supportive care alone for advanced non-small cell lung cancer. Cochrane Database of Systematic Reviews v. 5 , CD007309, 2010. Available at: <http://onlinelibrary.wiley. com/doi/10.1002/14651858.CD007309.pub2/abstract>. Accessed on: 05 May 2014.

O'REILLY, K.; MCLAUGHLIN, A.M.; BECKETT, W.S.; SIME, P.J. Asbestos-related lung disease. Am. Fam. Phys., v.75, n.5, p.683, 2007.

PESEZ, M.; BARTOS, J. Colorimetric and fluorimetric analysis of organic compounds and drugs. New York: Marcel Dekker., 1974. p. 628-630.

PFIZER ONCOLOGY: Pfizer oncology to present new clinical data from ten molecules across multiple tumor types" (Press release). Pfizer Oncology. Available at: <http://media. pfizer.com/files/news/press_releases/2010/asco_curtain_ raiser_052010.pdf $>$. Accessed on: 26 March 2014.

RODIG, S.J.; SHAPIRO, G.I. Crizotinib, a small-molecule dual inhibitor of the c-Met and ALK receptor tyrosine kinases. Curr. Opin. Investig. Drugs, v.11, n.12, p.1477-1490, 2010.

RON, W. Advances come in war on cancer. The Wall Street Journal, 07 June 2010. Available at: < http://goo. gl/08a2TS $>$. Accessed on: 28 March 2014.

ROWELL, N.P.; WILLIAMS, C.J. Radical radiotherapy for stage I/II non-small cell lung cancer in patients not sufficiently fit for or declining surgery (medically inoperable): a systematic review. Thorax, v.56, n.8, p.628638, 2001.

STRAND, T.E.; BRUNSVIG, P.F.; JOHANNESSEN, D.C.; SUNDSTROM, S.; WANG, M.; HORNSLIEN, K.; BREMNES, R.M.; STENSVOLD, A.; GARPESTAD, O.; NORSTEIN, J. Potentially curative radiotherapy for non-small cell lung cancer in Norway: a population-based study of survival. Int. J. Radiat. Oncol. Biol. Phys., v.80, n.1, p.133-141, 2011. 
TAN, W.W.; HARRIS, J.E.; HUQ, S. Non-small cell lung cancer. Medscape Reference, 2013. Available at: $<\mathrm{http}: / /$ emedicine. medscape.com/article/279960-overview>. Accessed on: 26 March 2014.

TOYO'OKA, T. Modern derivatization methods for separation sciences. Chichester: John Wiley and Sons Inc., 1999. p. $65-78$.

WORLD HEALTH ORGANIZATION. WHO. Geneva, Report 2005. Available at: $<$ http://www.who.int/cancer/en>. Accessed on: 10 Jan. 2014.
XALKORI: Xalkori (crizotinib) package insert. New York: Pfizer Labs., Division of Pfizer Inc., 2013. LAB-0441-6.0. Available at: $<$ http://labeling.pfizer.com/showlabeling. aspx?id=676 $>$. Accessed on: 28 March 2014.

Received for publication on $20^{\text {th }}$ May 2014 Accepted for publication on $02^{\text {nd }}$ December 2014 
